\title{
A Comparison of Phosphate Fertilizers for Tobacco
}

\author{
G. Samuels, E. G. Boneta-García, and F. Gonzälez-Vélez
}

\section{INTRODUCTION}

The major source of phosphorus in our tobacco fertilizers has been superphosphate (20-percent $\mathrm{P}_{2} \mathrm{O}_{5}$ ). However, newer forms of phosphates have appeared on the market. Some of these phosphate sources are more concentrated than superphosphate, several are more water-soluble, and others have nitrogen and potassium also associated with the phosphate radical. Inasmuch as phosphate fertilizers are normally considered necessary for good yields of tobacco in Puerto Rico, it was thought advisable to investigate these new phosphate sources for use as tobacco fertilizers. In cooperation with the Soils and Fertilizer Research Branch, Tennessee Valley Authority, phosphate materials were made available to the Agronomy and Horticulture Department of the Agricultural Experiment Station for experimentation. This paper deals with the response of tobacco to various phosphate sources on a Mabi clay at Gurabo.

\section{PROCEDURE}

The experiment on phosphate sources for tobacco was planted on a Mabi clay at the Gurabo Substation of the Agricultural Experiment Station. The Mabí clay is a grayish-brown plastic heavy soil with a pH 5.4.

The experiment was laid out in a rectangular lattice design with 12 fertilizer treatments replicated 3 times, making 36 plots in all. The plot size was 14 feet wide and 71/2 feet long, or approximately $1 / 415$ acre in area. Each plot had 4 rows, 42 inches apart, with 5 tobacco plants 18 incbes apart in the row, making a total of 20 plants. Seedlings were selected as to uniformity in regard to size and development, and were carefully transplanted to the experimental plots.

The fertilizers were applied in the soil 10 days after planting the tobacco seedlings. The fertilizer was placed in small semicircular bands at opposite sides of the plant and covered with soil. The fertilizer sources were ammonium sulfate (20-percent $N$ ), phosphate sources as noted in table 1 , and potassium sulfate (50-percent $\left.\mathrm{K}_{2} \mathrm{O}\right)$. The fertilizers were mixed at the rate of 100 pounds of nitrogen $(\mathrm{N})$, and 200 pounds each of phosphoric acid $\left(\mathrm{P}_{2} \mathrm{O}_{5}\right)$ and potash $\left(\mathrm{K}_{2} \mathrm{O}\right)$ per acre per treatment, except where noted.

The experiment was planted on November 15, 1959, and harvested on

${ }^{1}$ Agronomist and Research Agronomist, respectively, Agricultural Experiment Station, University of Puerto Rico, Rio Piedras, P.R. 
February 2, 1960. The plants were harvested by cutting the entire plant rather than by picking individual leaves. Although the quality of tobacco obtained was lower with the method of harvesting, there was much saving of both time and labor. Previous experiments carried on by A. S. Amy of this Station had shown that a conversion factor may be used to convert the values obtained from harvesting the entire tobacco plant at one time

TABLE 1.-Chemical and physical data on phosphate materials used in the experiment on phosphate sources for cigar-filler tobacco

\begin{tabular}{|c|c|c|c|c|c|c|c|c|}
\hline \multirow{2}{*}{ Material1 } & \multirow{2}{*}{ Grade } & \multirow{2}{*}{ Total N } & \multicolumn{3}{|c|}{$\mathrm{P}_{2} \mathrm{O}_{3}$} & \multirow{2}{*}{$\mathrm{K}_{2} \mathrm{O}$} & \multirow{2}{*}{$\mathrm{CaO}$} & \multirow{2}{*}{ Particle size } \\
\hline & & & Total & $\underset{\text { able }}{\text { Avail- }}$ & $\begin{array}{l}\text { Water- } \\
\text { soluble }\end{array}$ & & & \\
\hline & & Percent & Percent & Percent & Percent & Percent & Percens & Bresh \\
\hline $\begin{array}{l}\text { Ammonium meta- } \\
\text { phosphate }\end{array}$ & $16-72-0$ & 16 & 73 & 73 & 60 & - & - & $-6+35$ \\
\hline $\begin{array}{l}\text { Calcium metaphos- } \\
\text { phate, powder }{ }^{2}\end{array}$ & $0-62-0$ & - & 64 & 62 & - & - & 28 & -12 \\
\hline $\begin{array}{l}\text { Calcium metaphos- } \\
\text { phate, granules }\end{array}$ & $0-61-0$ & - & 63 & 62 & 10 & - & - & $-6+20$ \\
\hline $\begin{array}{l}\text { Concentrated su- } \\
\text { perphosphate }\end{array}$ & $0-48-0$ & - & 49 & 48 & 46 & 一 & 21 & -4 \\
\hline $\begin{array}{l}\text { Diammonium phos- } \\
\text { phate }^{3}\end{array}$ & $21-52-0$ & 20 & 52 & 52 & 52 & - & - & $-6+35$ \\
\hline $\begin{array}{l}\text { Dicalcium phos- } \\
\text { phate }\end{array}$ & $0-48-0$ & - & 48 & 48 & 1 & - & 39 & -12 \\
\hline $\begin{array}{l}\text { Potassium-calcium } \\
\text { pyrophosphate }\end{array}$ & $0-42-25$ & - & 46 & 42 & - & 26 & 18 & -35 \\
\hline $\begin{array}{l}\text { Potassium meta- } \\
\text { phosphate }\end{array}$ & $0-47-28$ & - & 50 & 48 & 20 & 28 & 10 & -35 \\
\hline $\begin{array}{l}\text { Simple or ordinary } \\
\text { superphosphate }\end{array}$ & $0-20-0$ & - & 21 & 20 & 13 & - & 34 & $-6+35$ \\
\hline
\end{tabular}

1 Obtained from the TVA Soils and Fertilizer Research Branch, Division of Agricultural Relations, Wilson Dam, Ala.

2 Conditioned with limestone.

3 Made from electric-furnace acid and conditioned with 3 percent of calcined dolomite.

to those to be expected when the normal method of harvesting individual leaves was employed.

The data in this experiment have been converted to comparable field values normally encountered in Puerto Rico by use of the conversion factors as suggested by Amy.

Tobacco variety Selección Olor was used because of its apparent resistance to Black Shank (Phytophthora nicotiani) a fungus disease of tobacco. This variety is primarily of the cigar-filler type. 


\section{RESULTS}

The results of the various phosphate sources on yields of tobacco are given in table 2.

\section{YIELDS}

There were significant responses to many of the phosphate sources used. Calcium metaphosphate powder gave the highest yields of tobacco per acre; next highest in yields, but still significantly lower than the highest yield, was the calcium metaphosphate in granules. Suggested reasons for the

TAnמ 2,-Tho influsnes of various phosphate sources on the pields and price of cioar-filler tobacco orown on a Mabt clay

\begin{tabular}{|c|c|c|c|c|}
\hline Phosphate sourcel & $\underset{P_{s} O_{6}}{\text { Content of }}$ & $\begin{array}{c}\text { Yiold of } \\
\text { cured tobacco } \\
\text { per acre }\end{array}$ & $\begin{array}{c}\text { Price of } \\
\text { cured tobacco } \\
\text { per acro }\end{array}$ & $\begin{array}{c}\text { Prico of } \\
\text { cured tobacco } \\
\text { per pound }\end{array}$ \\
\hline & Percent & Cwt. & Dollars & Cents \\
\hline Calcium metaphosphate, powder & 62 & 13.00 & 286.00 & 22.0 \\
\hline Calcium metaphosphate, granules & 61 & 11.34 & 210.92 & 18.6 \\
\hline Ammonium metaphosphate & 72 & 11.17 & 218.93 & 19.6 \\
\hline Potassium metaphosphate & 47 & 10.98 & 182.27 & 16.6 \\
\hline Dicalcium phosphate & 48 & 10.92 & 246.79 & 22.6 \\
\hline Potassium-calcium pyrophosphate & 42 & 10.77 & 268.17 & 24.9 \\
\hline Diammonium phosphate & 52 & 10.61 & 176.13 & 16.6 \\
\hline Concentrated superphosphate & 48 & 10.34 & 175.78 & 17.0 \\
\hline Simple superphosphate & 20 & 9.49 & 197.39 & 20.8 \\
\hline No phosphate & 0 & 8.92 & 155.20 & 17.4 \\
\hline \multicolumn{5}{|c|}{$\begin{array}{l}\text { Least significant difference needed between } \\
\text { treatments at: }\end{array}$} \\
\hline 5-percent level & & 1.57 & 63.25 & 5.3 \\
\hline 1-percent level & & 2.24 & 86.03 & - \\
\hline
\end{tabular}

powder giving higher yields than the granular form of calcium metaphosphate will be taken up under Discussion.

All phosphate sources used, with the exception of the simple and concentrated superphosphate, gave significantly higher yields of tobacco than the no-phosphate treatment. If either simple or concentrated superphosphate had been used as sources of phosphate for the Mabi clay no significant yield response would have been encountered. Yet these two phosphate sources are normally used in making tobacco fertilizer in Puerto Rico. However, many of the other phosphate sources used did give significant yield responses for tobacco.

If we use the simple or ordinary superphosphate as our basis of comparison, we find that calcium metaphosphate and ammonium metaphosphate gave significantly higher yields of toabcco per acre than the simple super- 
phosphate. The percentage yield increases in tobacco over the treatment with the simple superphosphate were 37 for powder and 20 for granular calcium metaphosphate, and 18 for ammonium metaphosphate.

Such phosphate sources as potassium metaphosphate and potassium-calcium pyrophosphate, both of which had potassium as well as phosphorus as part of their chemical composition, failed to produce significant yield increases over the simple superphosphate treatment.

It is interesting to note that the metaphosphate forms of phosphorus gave the highest yields of tobacco. Calcium, ammonium, and potassium metaphosphate placed first, second, and third, respectively, in yields of tobacco per acre (table 2 ).

\section{QUALITY}

When the quality of the tobacco as reflected by price is considered as compared to yields per acre, there were several differences in response to the phosphate fertilizer used. The calcium metaphosphate-powder treatment continued as the outstanding phosphate source, giving the highest dollar returns per acre. This was due to its high yields per acre and a good quality reflected in the 22 cents per pound received for the cured tobacco (table 2).

The granular form of calcium metaphosphate failed to give a significantly higher price per acre for tobacco as compared to the no-phosphate treatment. The loss of quality was reflected in the price received per pound of cured tobacco which dropped to 18.6 as compared to the 22 cents received for the powdered calcium metaphosphate. At present it cannot be explained why the granular form produced lower quality tobacco than the powdered calcium metaphosphate.

Dicalcium phosphate and potassium-calcium pyrophosphate, along with the mentioned calcium metaphosphate powder were the only sources that produced significant increases in price of tobacco per acre over the nophosphorus treatment. If we consider simple superphosphate as our basis of comparison only dicalcium phosphate- and calcium metaphosphate-powder treatments gave significant increases in price of tobacco per acre.

The highest price received per pound of tobacco was paid for that grown under the potassium-calcium pyrophosphate treatment; this was 24.9 cents per pound. Although the potassium-calcium pyrophosphate treatment placed sixth in yields of tobacco per acre, its influence upon tobacco quality was great enough to put it in second place in price of tobacco per acre.

\section{DISCUSSION}

The particle size of the phosphate material is of importance in relation to its availability or solubility. Availability of phosphate materials to crops generally increases with a decrease in particle size. This rule seems to hold 
for the calcium metaphosphate used in this experiment where the powder was superior to the granular form.

The particle sizes of these two materials are listed in table 1 , but a more precise study was made of the particle-size distribution of these two forms of calcium metaphosphate. For powdered calcium metaphosphate, 98 percent passed a 10-mesh screen, 56 percent a 20 -mesh screen, 21 percent a 40-mesh screen, and 12 percent a 60-mesh screen. Only 60 percent of the granular calcium metaphosphate passed a 10-mesh screen, 20 percent a 20-mesh screen, and none passed a 40-mesh screen. Thus there was a much greater quantity of fine particles in the powder than in the granular material. Ross and Jacob2 reported that calcined phosphate of 40-mesh or coarser was not so readily available to plants as was more finely divided material. Rogers et $a l .^{3}$ recommended that calcium metaphosphate be ground finer than 10-mesh. The amount of phosphate available from the powdered calcium metaphosphate appeared to be more usable by tobacco with such a short growing period than that from the granular form.

Not all forms of phosphate are readily soluble and available to the plant. To measure the concentration of phosphorus for fertilizer usage, the accepted standard is the percentage of citrate-soluble plus the water-soluble phosphorus. This is called the "available phosphoric acid" and is that which is used in the fertilizer analyses of the phosphate material. The higher the percentage of available phosphate, the more phosphate is assumed to present for the plant to use.

The percentage-phosphate $\left(\mathrm{P}_{2} \mathrm{O}_{5}\right)$ availability of the various phosphate sources used in this experiment were plotted against the yield of tobacco (fig. 1). A highly significant linear correlation was obtained between yields and percentage $\mathrm{P}_{2} \mathrm{O}_{5}$ availability. When the values obtained for the powdered calcium metaphosphate were omitted, the significance of the correlation increased. With all phosphate sources the prediction value of percentage $\mathrm{P}_{2} \mathrm{O}_{5}$ availability on yields of tobacco was 68 percent; without the powdered calcium metaphosphate the prediction value increased to 88 percent. As noted above the finer particle size of the powdered calcium metaphosphate increased its availability, and thus prevented it from being properly included with granular form in this correlation with yields.

The short growing season for tobacco demands a readily available supply of phosphates. The Mabi clay being naturally low in phosphorus cannot

2 Rogers, T. M., Pearson, R. W., and Ensminger, L. E., Comparative Efficiency of Various Phosphate Fertilizers, Soils and Fertilizer Phosphorus, Agronomy Monograph 4, 189-242, 1953.

${ }^{8}$ Ross, W. H. and Jacob, K. D., Availability of calcined phosphate and other new phosphatic materials as determined by chemical and vegetative tests, J.A.O.A.C. 20 231-49, 1937. 
properly supply all the phosphate needed in a short period of time. However, phosphate sources high in available $\mathrm{P}_{2} \mathrm{O}_{5}$ and of appropriately fine particle size can readily satisfy the needs of tobacco growing on a Mabi clay.

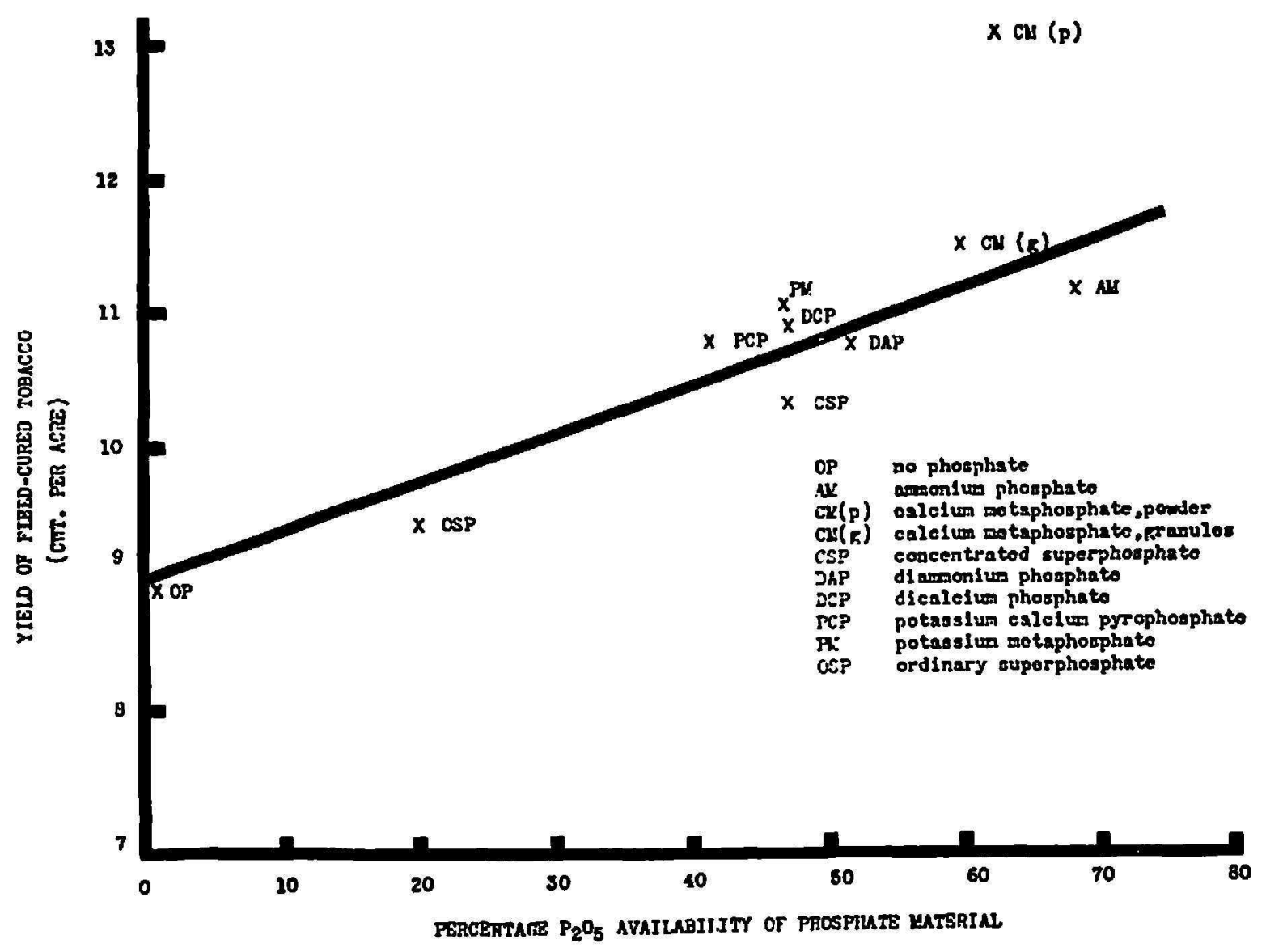

Fig. 1.-The influence of the percentage of $\mathrm{P}_{2} \mathrm{O}_{5}$ availability of the phosphate material on yields of tobacco on a Mabi clay in Puerto Rico.

\section{SUMMARY}

Various sources of phosphate were applied to cigar-filler tobacco grown on an acid Mabi clay. The results were as follows:

1. Highest yields of cured tobacco were obtained from the application of calcium metaphosphate with the powder significantly outyielding the granular form.

2. All phosphate sources used, with the exception of simple and concentrated superphosphate, gave significantly higher yields of tobacco than the no-phosphate treatment.

3. Calcium and ammonium metaphosphate treatments significantly outyielded simple superphosphate in tobacco per acre.

4. Considering the price of tobacco received per acre, calcium metaphos- 
phate powder gave the highest returns, but the granular form failed to give a significant price return over the no-phosphate treatment.

5. Dicalcium phosphate and potassium-calcium pyrophosphate, along with calcium metaphosphate powder, were the only sources which gave significant increases in price of tobacco per acre over the no-phosphate treatment.

6. The importance of the particle size of calcium metaphosphate on yields of tobacco was discussed.

7. A highly significant linear correlation was established between the percentage $\mathrm{P}_{2} \mathrm{O}_{5}$ availability of the phosphate fertilizer and yields of tobacco per acre.

\section{RESUMEN}

Se aplicaron varias fuentes de fosfato a siembras de tabaco para tripa en suelo Mabí arcilloso ácido, y los resultados fueron los siguientes:

1. Se obtuvieron rendimientos más altos de tabaco curado con la aplicación de metafosfato de calcio, siendo la producción significativamente mayor cuando dicho material se usó en polvo que en forma granulada.

2. Todas las fuentes de fosfato que se usaron, excepto el superfosfato simple y el concentrado, propiciaron rendimientos significativamente más altos que cuando no se usó fosfato.

3. Los tratamientos a base de metafosfato cálcico y amónico hicieron posible una mayor producción por cuerda de tabaco que los efectuados a base de superfosfato simple.

4. Considerando el precio del tabaco por cuerda, la aplicación de polvo de metafosfato cálcico dió los mejores resultados; pero no así la forma granulada sobre el tratamiento sin ningún fosfato.

5. El fosfato dicálcico y el pirofosfato potásico-cálcico, junto a polvo de metafosfato cálcico fueron los únicos abonos que posibilitaron un aumento significativo en el precio por cuerda del tabaco, sobre el tabaco sin ningún tratamiento.

6. Se discutió la importancia del tamaño de las partículas de metafosfato cálcico en el rendimiento del tabaco.

7. Se estableció una correlación lineal altamente significativa entre el porcentaje de disponibilidad del $\mathrm{P}_{2} \mathrm{O}_{5}$ de los abonos fosfatados y los rendimientos de tabaco por cuerda. 